International Research Journal of Management, IT \& Social Sciences
Available online at https://sloap.org/journals/index.php/irjmis/
Vol. 7 No. 3, Month 2020, pages: 116-125
ISSN: 2395-7492
https://doi.org/10.21744/irjmis.v7n3.928

\title{
The Effect of Earning Management, Managerial Ownership and Firm Size in the Return of Acquisition Companies in Indonesia Stock Exchange 2011-2017 Period
}

Ni Luh Andini ${ }^{\text {a }}$ I Made Sukartha ${ }^{\text {b }}$

\section{Article history:}

Submitted: 09 March 2020

Revised: 18 April 2020

Accepted: 27 May 2020

\section{Keywords:}

earnings management;

firm size;

Indonesia stock exchange (BEI);

managerial ownership;

stock returns;

\begin{abstract}
This research was conducted to see the effect of earnings management, managerial ownership, and firm size, and net profit margin (NPM) as a control variable on stock returns. The research location is on the Indonesia Stock Exchange (BEI) in 2018 by accessing the official website of the Indonesia Stock Exchange, www.idx.co.id, and using the Indonesian Capital Market Directory which provides complete company financial statement information and explanations and other information. The population used in this study were companies that acquired other companies in the period 2011 to 2017 and were listed on the Indonesia Stock Exchange (IDX) totaling 75. The total sample that was ultimately used in this study was 30 acquiring companies selected by the purposive sampling method. The analytical method used in this study is the multiple linear regression analysis. The results of this study found that based on the results of research on the effect of earnings management, managerial ownership, and firm size on acquirer stock returns in 2011-2017, of the four research variables one of them is net profit margin (NPM) as a control variable affecting stock returns.
\end{abstract}

International research journal of management, IT and social sciences (C) 2020. This is an open access article under the CC BY-NC-ND license (https://creativecommons.org/licenses/by-nc-nd/4.0/).

\section{Corresponding author:}

Ni Luh Andini,

Faculty of Economics and Business, Udayana University, Denpasar, Indonesia.

Email address: andinibgs@gmail.com

Faculty of Economics and Business, Udayana University, Denpasar, Indonesia

Faculty of Economics and Business, Udayana University, Denpasar, Indonesia 


\section{Introduction}

Strategy development is carried out by the company to maintain its existence. One strategy option that can be chosen by companies is to do a business combination. A business combination is a union of two or more separate companies into an economic entity because a company is one with another company or obtains control over the assets and operations of another company, the type of business combination can be divided into two, namely acquisition and pooling of ownership which is commonly called a merger, (PSAK No.22).

Business combinations especially acquisitions are usually done by targeting companies that are weak and have economic problems. This causes the investors to be very selective in choosing the acquiring company to be invested in. This is what underlies the acquirer to do earnings management to be able to remind the company's profits on the company's financial statements before the acquisition. Management's goal is to attract investors to invest their capital in the company because they believe they will get a large return.

Shareholders' interests and different management can cause conflict. As is explained in Agency Theory (Agency Theory). Tarjo \& Hartono (2003) in Dewi (2008), stated that conflicts between shareholders and management often occur because management tends to try to prioritize personal interests. The conflict between shareholders and management is called the "Agency Conflict". The conclusion of the statement of Jensen \& Meckling (1976) is that the more concentrated ownership of the company to one person, the control will become stronger and tend to reduce agency conflict. Asymmetric information between investors and management opens up opportunities for companies to conduct earnings management to maximize their utility with a bonus program or to delay the replacement of managers, (Healy, 1985; Dewi \& Wirama 2019; Pourciau, 1993; Beneish, 1997).

Watt \& Zimmerman (1978) in Handayani \& Rachadi (2009), stated that firm size as a proxy for the political cost is considered to be very sensitive to earnings reporting behavior. From the same article, Bartov \& Simko (2002), state that medium and large-sized companies have stronger pressure than their stakeholders so that the company's performance is in line with the expectations of its investors compared to small companies. This encourages management to meet these expectations. In contrast, Burgstahler \& Dichev (1997), provide different empirical evidence that all firm sizes are proven to always report positive earnings, to avoid earnings losses or earnings decreases. Based on these studies and their descriptions, this study aims to determine the effect of earnings management by the acquirer before the acquisition date of the acquirer's stock returns. The next objective is to determine the effect of managerial ownership and firm size on the acquirer's stock returns (Zhou, 2001; Himmelberg et al., 1999).

In previous studies, researchers examined more company performance and stock returns generated from the fundamental side by using the company's financial ratios. The management in the company compiles financial reports every period to be able to control the results of the calculation of the company's ratio. Previous research by Susilowati \& Turyanto (2011), examined the reaction signal of profitability ratios and solvency ratios referring directly to company stock returns. The results of this study indicate that DER is proven to have a positive and significant effect on stock returns; while EPS, NPM, ROA, and ROE do not affect the stock returns of manufacturing companies listed on the Stock Exchange from 2006 to 2008. Furthermore, the EPS, NPM, ROA, ROE, and DER variables can predict the stock returns of listed manufacturing companies on the Stock Exchange from 2006 to 2008. Earlier in 2004, Payamta and Setiawan researched company performance measured using financial ratios and stock prices before and after mergers and acquisitions. The results of his research showed that there was no significant difference in performance both in terms of ratios and stock prices for two years before and after mergers and acquisitions.

\section{Literature review and hypotheses development}

Earnings management is the use of accrual basis by management when preparing financial statements so that managers can manage earnings by increasing, decreasing, or leveling profits. Earnings management results that the market performance of companies that use shares as a method of payment for mergers and acquisitions is better than the method of payment with cash. In the research of Rahman \& Bakar (2002), it is proven that there is earnings management through discretionary accruals in acquiring companies before mergers and acquisitions in Malaysia in the year before the acquisition. As for the Positive Accounting Theory, there are two points of view in managing earnings. An efficient viewpoint can support the existence of earnings management actions by the acquirer as it approaches the merger and acquisition payment. When payments are made with shares, the company will increase profits on its financial statements. It can be concluded that the company is trying to affect the market by publishing positive financial information. This is consistent with agency theory supported by earnings management theory and the empirical study above.

Andini, N. L., \& Sukartha, I. M. (2020). The effect of earning management, managerial ownership and firm size in the return of acquisition companies in Indonesia Stock Exchange 2011-2017 period. International Research Journal of Management, IT and Social Sciences, 7(3), 116-125. https://doi.org/10.21744/irjmis.v7n3.928 
H1: The management of the acquiring company carries out earnings management by raising profits on the financial statements reported at the time of publication before the acquisition announcement

Agency theory is the relationship or contract between principal and agent. The Principal employs agents to carry out tasks to fulfill the principal's interests. In a company, which includes the principal are shareholders, while included in the agent is the CEO (Chief Executive Officer). Strengthening the company's stock price in the market is important for companies to show good prospects in the future. A stronger stock price is expected by the company to be obtained through management which is used to convey internal company information. Some studies document the use of earnings management as a mechanism that facilitates efficient communication between managers and users of information. For example, studies conducted by Bartov et al. (2002); Lev \& Zambon (2003), who model information asymmetry and define earnings management as rational equilibrium behavior. To strengthen the ability of investors to predict corporate performance, earnings management is used to improve the relevance of financial reporting.

H2: Earnings management has a positive effect on the acquirer's stock returns.

Managers get the opportunity to get involved in shared ownership to equalize their position with shareholders. Through this policy, managers are expected to produce a good performance and bring dividends to a low level. By setting a low dividend, the company has high retained earnings so that it has relatively high internal funding sources. Managerial ownership proxy uses the percentage of the manager and director ownership of total common stock outstanding (Chen \& Steiner, 1999 in Nuringsih, 2005). Theoretically, management who has a high percentage of share ownership will act like someone who holds an interest in the company. This assumption is in line with contract-based theory (contracting-based theory) which shows that management will be efficient in choosing accounting methods that will provide added value to the company (Christie \& Zimmerman, 1994; Samiee \& Walters, 1990; Slovin et al., 1992). Managers who hold company shares will be reviewed by the parties involved in the contract such as the selection of an audit committee that creates requests for quality financial reporting by shareholders, creditors, and users of financial statements to ensure the efficiency of the contracts made. Thus, management will be motivated to prepare quality financial reports. This would reflect better contract conditions (Ball et al., 2003) in Mahariana \& Ramantha (2014).

H3: Managerial ownership has a positive effect on the acquirer's stock returns.

The firm size (size) describes the size of a company that is indicated by total assets, total sales, average sales level, and average total assets. In their research, Setiyono et al. (2016), measure firm size using total assets. The rate of return of shares of large companies is greater than the stock returns of small-scale companies because the growth rate of large companies is relatively greater than in small companies. Therefore, investors will be more speculated to choose large companies with the hope of obtaining a large return. Companies that have a large number of total assets have reached the maturity stage because at that stage cash flow has been positive and is considered to have better prospects in the relatively long term. Some researchers use firm size as a proxy for political sensitivity and managerial behavior in reporting financial performance (Pacecca, 1995). Zimmerman (1983) in Handayani \& Rachadi (2009), suggests using the proxy of firm size in the framework of the political cost. Based on the size hypothesis presented by Watt \& Zimmerman (1986), it assumes that large companies are politically more likely to transfer political costs within the political process framework, compared to small companies. Some researchers have succeeded in proving that political processes have an impact on the choice of accounting procedures by large companies (Watt \& Zimmerman, 1986).

H4: Firm size has a positive effect on the acquirer's stock return.

\section{Materials and Methods}

The research location is on the Indonesia Stock Exchange (BEI) in 2018 by accessing the official website of the Indonesia Stock Exchange, www.idx.co.id, and using the Indonesian Capital Market Directory which provides company financial statement information along with other explanations and other information. This study is the financial statements of companies that acquired other companies in the period 2011 to 2017 listed on the Indonesia Stock Exchange (IDX), to obtain information related to earnings management, managerial ownership, firm size, and stock returns of the company.

The population used in this study are companies that acquired other companies in the period 2011 to 2017 and were listed on the Indonesia Stock Exchange (IDX). The sample in this study was obtained by purposive sampling method. Purposive sampling is a non-random sampling technique where the researcher determines sampling by determining 
specific characteristics that are appropriate to the purpose of the study so that it is expected to answer the research problem. The criteria used are as follows:

1) Companies that make acquisitions of other companies that make payments using shares in the 2011-2017 study period

2) Acquisition companies that only make acquisition once in a year.

The data collection method used in this study is the documentation method. The documentation method is a method of collecting data by taking data that is already available, such as notes, transcripts, books, agendas, and so on. The data in this study are audited financial statements of acquiring companies listed on the Indonesia Stock Exchange (BEI) in 2011-2017 that have been published obtained from the Indonesian Capital Market Directory (ICMD) and on the Indonesia Stock Exchange website, www.idx.co. id.

Multiple linear regression analysis is used to test whether between earnings management, managerial ownership, and firm size affect the acquirer's stock returns. With the following equation:

$$
Y_{t+1}=\alpha+\beta_{1} X_{1}+\beta_{2} X_{2}+\beta_{3} X_{3}+\beta_{4} X_{4}+\varepsilon
$$

Information:

$\mathrm{Y}=$ Stock returns

$\alpha=$ Constant

$\beta=$ Regression Coefficient

$\mathrm{X} 1$ = Earning Management (measured by Discretionary Accrual)

X2 = Managerial Ownership

$\mathrm{X} 3$ = Firm size

X4 = Net Profit Margin

$\varepsilon=$ confounding component

\section{Results and Discussions}

\section{Descriptive Statistics Results}

Descriptive analysis of research data is used to provide information about the characteristics of stock return variables, earnings management, managerial ownership, and firm size which include average values, and standard deviations. Descriptive statistics of the variables of this study are presented in table 1.

Table 1

Descriptive statistics

\begin{tabular}{llllll}
\hline & $\mathrm{N}$ & Min & Max & Mean & Std. Deviation \\
\hline $\mathrm{X}_{1}$ & 30 & $-0,4168$ & 0,0570 & $-0,0327$ & 0,1036 \\
$\mathrm{X}_{2}$ & 30 & 0,0000 & 0,9573 & 0,0590 & 0,2034 \\
$\mathrm{X}_{3}$ & 30 & 20,8813 & 31,5394 & 27,6693 & 1,9029 \\
$\mathrm{Y}$ & 30 & $-0,9051$ & 0,1468 & $-0,0292$ & 0,1749 \\
$\mathrm{X}_{4}$ & 30 & $-0,8882$ & 0,8835 & $-0,0286$ & 0,3501 \\
Valid N (listwise) & 30 & & & & \\
\hline
\end{tabular}

Data Sekunder, 2020

Discretionary Accrual (DA) is used as a tool for calculating earnings management. Table 5.4 shows the earnings management variable (X1) showing the average value - $0.0327(-3.27 \%)$. This value indicates that the earnings management carried out by each acquirer management company that was sampled in this study from 2011 to 2017 was average in the form of income decreasing or reduced its profit by $3.27 \%$ of the company's total assets. The managerial ownership variable (X2) has an average value of $0.0589(5.89 \%)$. This value shows that the average percentage of managerial ownership in the acquirer company that became the sample of this study was $5.89 \%$, meaning that of the total outstanding shares of $5.89 \%$ owned by management.

Andini, N. L., \& Sukartha, I. M. (2020). The effect of earning management, managerial ownership and firm size in the return of acquisition companies in Indonesia Stock Exchange 2011-2017 period. International Research Journal of Management, IT and Social Sciences, 7(3), 116-125. https://doi.org/10.21744/irjmis.v7n3.928 
The firm size variable is proxied by Ln's total sales. The use of natural $\log (\mathrm{Ln})$ is intended to reduce excessive data fluctuations. If the total value of sales is used, the value of the variable will be very large. The firm size variable (X3) shows an average score of 27.67. Based on measurements of firm size referring to law no.9 of 1995, where the firm size is proxied by the natural logarithm of the total sales, the value indicates that the average acquirer company in Indonesia from 2011 to 2017 which became a research sample can be grouped in medium or large companies. Table 1 above shows that the stock return variable has an average value of -0.0292 or $-2.29 \%$. While the standard deviation value is 0.1749 this data shows that the company that became the research sample on average experienced a decrease in stock returns of $2.29 \%$.

Net Profit Margin (NPM) as a control variable in this study shows an average value of -0.0286 . This shows that the net profit obtained by the company that was sampled in the period 2011 to 2017 decreased by $2.86 \%$ of total sales. These negative conditions indicate a declining company performance. The coefficient on Net Profit Margin (NPM) is 0.328 . These results indicate that if NPM rises by $1 \%$ assuming the other variables are fixed, it will be followed by an increase in stock returns of $0.328 \%$.

\section{Results of multiple linear regression analysis}

Table 2

Results of multiple linear regression analysis

\begin{tabular}{|c|c|c|c|c|c|c|}
\hline \multirow{2}{*}{\multicolumn{2}{|c|}{ Model }} & \multicolumn{2}{|c|}{ Unstandardized Coefficients } & \multirow{2}{*}{$\begin{array}{l}\text { Standardized Coefficients } \\
\text { Beta }\end{array}$} & \multirow[b]{2}{*}{$\mathrm{t}$} & \multirow[b]{2}{*}{ Sig. } \\
\hline & & $\mathrm{B}$ & Std. Error & & & \\
\hline \multirow[t]{5}{*}{1} & (Constant) & 0,014 & 0,389 & & 0,036 & 0,971 \\
\hline & $X_{1}$ & 0,013 & 0,258 & 0,008 & 0,050 & 0,961 \\
\hline & $\mathrm{X}_{2}$ & $-0,036$ & 0,131 & $-0,042$ & $-0,275$ & 0,785 \\
\hline & $X_{3}$ & $-0,001$ & 0,014 & $-0,012$ & $-0,081$ & 0,936 \\
\hline & $\mathrm{X}_{4}$ & 0,328 & 0,076 & 0,657 & 4,323 & 0,000 \\
\hline
\end{tabular}

a. Dependent Variable: Y

Secondary Data, 2020

The first hypothesis states that the management of the acquiring company carries out earnings management by increasing company profits at the time of publication before the acquisition announcement. Testing this hypothesis by looking at appendix 1, on the results of the calculation of Discretionary Accrual (X1). There are 16 companies with negative discretionary accruals. While the remaining 14 companies received positive discretionary accruals. Based on the results of the discrete statistical analysis presented in table 5.5, it can be seen that the average value of DA (X1) is negative at $-0.0326(-3.26 \%)$. This means that on average, sample companies do earnings management with income decreasing patterns. However, based on the results of the one-sample test in table 5.8 it can be seen that the value of the p-value of DA data (X1) of the sample company is greater than the 0.05 significant level of 0.095 . This means that the earnings management carried out by the sample company is not significant. Thus this research rejects the first hypothesis which states that the acquirer management manages income-increasing earnings management at the time of publication before the acquisition.

The second hypothesis (H2) states that earnings management has a positive effect on the stock returns of the acquirer. The testing of this effect is done by looking at table 2. The SPSS calculation results in table 2 show the value of $t$ arithmetic DA (X1) of 0.050 with a significance level of 0.961 which is greater than the real level of 0.05 . Because the significance value of the variable is greater than 0.05 , the second hypothesis (H2) is rejected. This means that earnings management does not affect the acquirer's stock returns.

Hypothesis 3 states that managerial ownership has a positive effect on stock returns. The testing of this effect is done by looking at table 2 . The results in table 2 show t count KM (X2) of -0.275 with a significance level of 0.785 which is greater than 0.05 . Significance value that is greater than the real level means the third hypothesis (H3) is rejected, meaning that managerial ownership does not affect the stock returns of the acquirer.

Hypothesis 4 states that firm size has a positive effect on the acquirer's stock return. The testing of this effect is carried out by looking at table 2 . The results in table 2 show the t-count LnFM (X3) of 0.081 with a significance of 0.936 which is greater than the significance level of 0.05 . This causes $\mathrm{H} 4$ to be rejected, which means the firm size does not affect the acquirer's stock return. 


\section{Model Feasibility Test (F Test)}

The F test was used to determine the feasibility of the regression model as a tool to be analyzed that tested the effect of the independent variables simultaneously on the dependent variable. Based on table 3, the F significance value of 0.006 is less than 0.05 , which means that the independent variable simultaneously affects stock returns, so that the independent variables in the model are suitable for predicting the dependent variable.

Table 3

Model feasibility test results (Test F)

\begin{tabular}{lllllll}
\hline Model & & Sum of Squares & df & Mean Square & F & Sig. \\
\hline 1 & Regression & 0,380 & 4 & 0,095 & 4,675 & $0,006^{\text {b }}$ \\
& Residual & 0,508 & 25 & 0,020 & & \\
& Total & 0,887 & 29 & & &
\end{tabular}

a. Dependent Variable: Y

Secondary Data, 2020

Results coefficient of determination (R2)

The coefficient of determination test is useful for predicting and seeing how much the contribution of effect is given by variable X simultaneously (together) on the Y variable. Based on table 4 of the SPSS output of "Model Summary" it is known that the coefficient of determination or Adjusted R Square is 0.336. It means that the total effect of the four independent variables is $33.6 \%$ on stock returns $(\mathrm{Y})$, while the other $66.4 \%$ is explained by other variables not used in this study.

Table 4

Determination coefficient test results

\begin{tabular}{llllll}
\hline & & & & \multicolumn{2}{l}{ Std. Error of the } \\
Model & $\mathrm{R}$ & R Square & Adjusted R Square & Estimate & Durbin-Watson \\
\hline 1 & $0,654^{\mathrm{a}}$ & 0,428 & 0,336 & 0,142 & 2,073
\end{tabular}

a. Predictors: (Constant), $\mathrm{X}_{1}, \mathrm{X}_{2}, \mathrm{X}_{3}, \mathrm{X}_{4}$

b. Dependent Variable: Y

Secondary Data, 2020

Earning management by the acquisition company when the publication is not significant

The results of the first hypothesis testing that showed a significance level greater than 0.05 showed earnings management by the acquirer at the time of publication before the acquisition was not significant. This means that there is no earnings management in the acquirer company which became a research sample from 2011 to 2017 . The results of this study are not following the signaling theory which explains why companies have the incentive to provide financial statement information to external parties. The announcement of accounting information gives a signal that the company has good prospects in the future so that one of the goals of the company doing earnings management is to provide Good News signals to outsiders. This finding is not following the first hypothesis which states that the acquirer company carries out earnings management at the time of publication before acquisition by increasing company profits (income increasing).

The results of this study are not in line with empirical evidence from Dewi (2018); in Rahman \& Bakar (2002), who found that companies do earnings management at the time of publication before the acquisition by way of income increasing. Judging from the value of the discretionary Accrual (DA), it shows that the management of the acquiring company carries out earnings management by lowering the company's earnings on the report at the time of publication before the acquisition announcement. There are 16 acquirer companies with negative discretionary accruals, which means that the company carries out earnings management using the income decreasing method. While the remaining 15 companies have positive discretionary accruals, which means that the company's management manages earnings with the income increasing method.

Andini, N. L., \& Sukartha, I. M. (2020). The effect of earning management, managerial ownership and firm size in the return of acquisition companies in Indonesia Stock Exchange 2011-2017 period. International Research Journal of Management, IT and Social Sciences, 7(3), 116-125. https://doi.org/10.21744/irjmis.v7n3.928 
Judging from table 1, the results of descriptive statistical analysis show the average value of discretionary accruals (X1) of $-0.0327(-3.27 \%)$, which means the average acquirer company that was sampled in this study during 2011 to 2017 do earnings management by reducing the company's profit by $3.27 \%$. From the results of data processing, it shows that most of the total accrual calculations produce negative values. This is because the sample company has a smaller net income than operating cash flow.

This study is in line with research conducted by Watts \& Zimmerman (1986), which states that the acquirer company chooses not to manipulate earnings to be higher when it tends to detect large earnings management. This can be caused because the target company can pay accountants and investment bankers to evaluate the acquirer's financial statements, and ensure that the financial statements contained therein are free from manipulation.

\section{Earning management does not affect the acquirer's stock returns}

Earnings management conducted by the acquirer at the time of publication before the acquisition aims to increase the stock price before the stock merger to reduce the acquisition costs of the target acquisition company. One point of view in the Positive Accounting Theory states that an efficient point of view can support the existence of earnings management actions by the acquirer when approaching merger and acquisition payments. When payments are made with shares, the company will increase profits on its financial statements. Based on the results of statistical testing it is known that $(\mathrm{H} 2)$ proposed in this study is rejected, meaning that there is no effect of earnings management on the acquirer's stock returns. The results of this test are not in line with research conducted by Ardianti (2013) and Ferdiansyah (2012) who succeeded in proving a positive effect between earnings management and stock returns.

In Table 5.8, the results of the regression analysis show the earnings management coefficient (X1) of 0.013 with a significance level of 0.961 whose value is higher than the real level of 0.05 . The results of the descriptive statistical analysis in table 5.7 show that the earnings management variable (X1) obtained an average value of $-0.0327(-3.27 \%)$. This value means that the average management of the acquirer company that was sampled in this study carried out earnings management by reducing the amount of its profit by $3.27 \%$ of the company's total assets. Stock return variable (Y) obtained an average value of $-0.0292(-2.92 \%)$ which means that the average acquirer company that became the research sample experienced a decrease in stock returns of $2.92 \%$.

Judging from the calculation of cumulative return appendix 3 there is a significant negative value (-) of $14.49 \%$ in PT Harum Energy Tbk. So this causes the earnings management variable to hurt the acquirer's return. This study is in line with research conducted by Fanani (2006) to get the result that the Accrual Discretionary variable does not have a significant effect on stock returns. Empirical evidence indicates that changes in accounting methods that do not affect the company's cash flow will not affect stock prices, or in other words, investors will not be fooled by an increase in accounting profit that does not affect the company's cash flow (Wolk \& Tearney 1997; Healy \& Wahlen 1998).

\section{Managerial ownership does not affect the return of the acquisition company}

The third hypothesis in this study is that managerial ownership has a positive effect on the stock returns of the acquirer. Managerial ownership in a company is expected to encourage management to improve company performance, and it is expected that the company's return is better with good managerial ownership. Agency Theory (Agency Theory) by Jansen \& Meckling (1976) which states that ownership of shares by company management will make management try to be more active in efforts to meet the interests of shareholders who also are themselves. Management opportunistic behavior that increases the amounts of discretionary accruals causes reported earnings to increase. In an efficient market, the increase in the amount of profit will be reacted positively by the market so that the stock market price will rise which will be able to increase stock returns.

The coefficient value of the managerial ownership variable (X2) is negative 0.036 . This means that there is a negative relationship between managerial ownership with stock returns and the significance value of this variable is above 0.05 which is equal to 0.785 so that the third hypothesis $(\mathrm{H} 3)$ is rejected. The results of this test are following research by Sudarma (2005); Othman et al. (2010), who found that managerial ownership does not affect firm value. This happens because the percentage of share ownership owned by directors used as a sample is relatively small. It can be concluded that the existence of managerial ownership in a company has not been able to encourage management to improve company performance so that the market does not react to the company's annual financial statement submission. This happens because the level of managerial ownership in a company is relatively small. So it has not been able to improve management performance, because the management does not feel that it owns the company. 
The firm size does not affect the return of the acquisition company

The fourth hypothesis in this study is that firm size has a positive effect on stock returns. According to Setiyono and Amanah, investors will be more speculated to choose large companies with the hope of obtaining large returns as well. The results showed the coefficient of firm size (X3) of -0.001 with a significance level of 0.936 which was greater than the real level of 0.05 so that the fourth hypothesis was rejected. This means that there is no influence between the firm size with the stock returns of the acquirer. This high significant level indicates that the firm size does not affect stock returns. The insignificant test results show that the firm size when publishing financial statements is not informative enough and is no longer a concern of investors in taking investment decisions and estimating returns in this observation period.

The results of this test are following research conducted by Setiono et al. (2017); Berggrun et al. (2016); Murhadi (2011), which states that the firm size does not affect stock returns because the growth of a company is not only seen from the size and firm size. Investors assume that large companies cannot always provide a large rate of return and vice versa, small companies do not rule out the possibility of providing a large rate of return.

\section{Conclusion}

Proof of earnings management in this study uses a modified Jones model, where most of the discretionary accrual results are negative. To get a broader picture of whether the acquirer company did earnings management before mergers and acquisitions, researchers can make comparisons with a sample of companies that did not do mergers and acquisitions. Researchers can also make comparisons with companies that conduct mergers and acquisitions using cash financing.

Investors are expected to have the ability to detect earnings management because when earnings management is not detected, the description of the returns to be obtained by investors will not be as expected. Regarding managerial ownership, it is expected that managers who have the opportunity to own shares are expected to be able to produce better performance. Asymmetric information between management and investors can be minimized by motivating managers to return to action in the interests of shareholders by providing compensation such as salaries or bonuses and direct intervention from investors.

Related to the results of the study which showed that firm size did not affect stock returns, the sample in this study was categorized as a medium / large company, but the results of the study showed that firm size did not affect stock returns. Investors do not have to choose large companies to invest in. Many studies have shown that firm size does not affect stock returns. This is because the growth of a company is not only seen from the size and firm size.

\section{Conflict of interest statement}

The authors declared that they have no competing interests.

Statement of authorship

The authors have a responsibility for the conception and design of the study. The authors have approved the final article.

\section{Acknowledgments}

We are grateful to two anonymous reviewers for their valuable comments on the earlier version of this paper.

Andini, N. L., \& Sukartha, I. M. (2020). The effect of earning management, managerial ownership and firm size in the return of acquisition companies in Indonesia Stock Exchange 2011-2017 period. International Research Journal of Management, IT and Social Sciences, 7(3), 116-125. https://doi.org/10.21744/irjmis.v7n3.928 


\section{References}

Abdul Rahman, R., \& Abu Bakar, A. (2002). Earnings management and acquiring firms preceding acquisitions in Malaysia. https://dx.doi.org/10.2139/ssrn.318219

Ardianti, E. (2013). Pengukuran Tingkat Likuiditas Pada Sektor Perbankan Yang Go Public Dengan Analisis Cash Ratio, Loan To Deposit Ratio (Ldr) Dan Loan To Asset Ratio (LAR)(Studi Empiris Pada Bank Persero Yang Go Public di Bursa Efek Indonesia Tahun 2006-2012) (Doctoral dissertation, Universitas Muhammadiyah Surakarta).

Ball, S. J. (2003). Class strategies and the education market: The middle classes and social advantage. Routledge.

Bartov, E., Givoly, D., \& Hayn, C. (2002). The rewards to meeting or beating earnings expectations. Journal of accounting and economics, 33(2), 173-204. https://doi.org/10.1016/S0165-4101(02)00045-9

Beneish, M. D. (1997). Detecting GAAP violation: Implications for assessing earnings management among firms with extreme financial performance. Journal of accounting and public policy, 16(3), 271-309. https://doi.org/10.1016/S0278-4254(97)00023-9

Berggrun, L., Lizarzaburu, E., \& Cardona, E. (2016). Idiosyncratic volatility and stock returns: Evidence from the MILA. Research in International Business and Finance, 37, 422-434. https://doi.org/10.1016/j.ribaf.2016.01.011

Brennan, M. J., \& Subrahmanyam, A. (1996). Market microstructure and asset pricing: On the compensation for illiquidity in stock returns. Journal of financial economics, 41(3), 441-464. https://doi.org/10.1016/0304405X(95)00870-K

Burgstahler, D., \& Dichev, I. (1997). Earnings management to avoid earnings decreases and losses. Journal of accounting and economics, 24(1), 99-126. https://doi.org/10.1016/S0165-4101(97)00017-7

Chen, C. R., \& Steiner, T. L. (1999). Managerial ownership and agency conflicts: A nonlinear simultaneous equation analysis of managerial ownership, risk taking, debt policy, and dividend policy. Financial review, 34(1), 119-136. https://doi.org/10.1111/j.1540-6288.1999.tb00448.x

Christie, A. A., \& Zimmerman, J. L. (1994). Efficient and opportunistic choices of accounting procedures: Corporate control contests. Accounting review, 539-566.

Dewi, D. N. (2018). Positive Reaction to Accounting Restatement: The Episode of Reasons and Earning

Changes. Jurnal Ilmiah ESAI, 8(3), 211-219. http://dx.doi.org/10.25181/esai.v8i3.948

Dewi, N. P. S. P., \& Wirama, D. G. (2019). Debt covenant slack, earnings management, and value relevance of accounting information. International research journal of management, IT and social sciences, 6(4), 86-96. https://doi.org/10.21744/irjmis.v6n4.661

Dewi, S. C. (2008). Pengaruh kepemilikan managerial, kepemilikan institusional, kebijakan hutang, profitabilitas dan ukuran perusahaan terhadap kebijakan dividen. Jurnal Bisnis dan Akuntansi, 10(1), 47-58. https://doi.org/10.34208/jba.v10i1.252

Fanani, Z. (2006). Manajemen Laba: Bukti dari Set Kesempatan Investasi, Utang, Kos Politis dan Konsentrasi Pasar pada Pasar yang Sedang Berkembang. Simposium Nasional Akuntansi IX. Padang Tanggal, 23-26.

FASB. (1978). "Statement of Financial Accounting Concepts No. 1, Objectives of Financial Reporting by Business Enterprises." Stanford, C.T., Financial Accounting Standard Board (FASB).

Ferdiansyah, D. P. (2012). Pengaruh Manajemen Laba Terhadap Return Saham dengan Kecerdasan Investor sebagai Variabel Moderating (Studi pada Perusahaan Manufaktur Sektor Aneka Barang Konsumsi yang Terdaftar di Bursa Efek Indonesia periode Tahun 2008-2011). Jurnal Sains Manajemen \& Akuntansi, 4.

Handayani, R. S., \& Rachadi, A. D. (2009). Pengaruh ukuran perusahaan terhadap manajemen laba. Jurnal bisnis dan akuntansi, 11(1), 33-56. https://doi.org/10.34208/jba.v11i1.109

Healy, P. (1985). The impact of bonus schemes on the selection of accounting principles. Journal of Accounting and Economics, 7(1-3), 85-107.

Healy, P. M., \& Wahlen, J. M. (1998). A review of the earnings management literature and its implications for standard setting. Boston. Accounting Horizons, 365-383.

Himmelberg, C. P., Hubbard, R. G., \& Palia, D. (1999). Understanding the determinants of managerial ownership and the link between ownership and performance. Journal of financial economics, 53(3), 353-384. https://doi.org/10.1016/S0304-405X(99)00025-2

Jensen, M., \& Meckling, W. (1976). Theory of the firm: Management behavior, agency costs and capital structure. Journal of financial economics, 3(4), 305-60.

Lev, B., \& Zambon, S. (2003). Intangibles and intellectual capital: an introduction to a special issue. European Accounting Review, 12(4), 597-603. https://doi.org/10.1080/0963818032000162849

Mahariana, I. D. G. P., \& Ramantha, I. W. (2014). Pengaruh Kepemilikan Manajerial dan Kepemilikan Institusional terhadap Manajemen Laba Pada Perusahaan Manufaktur di BEI. E-Jurnal Akuntansi, 688-699. 
Murhadi, W. R. (2011). Good corporate governance and earning management practices: An Indonesian cases. Jurnal Manajemen, 10(2), 143-155.

Nuringsih, K. (2005). Analysis of Effect of Managerial Ownership, Debt Policy, ROA, and Size of Corporate Dividend Policy: Studies from 1995 to 1996. Indonesian Journal of Accounting and Finance, 2(2), 103-123.

Othman, R., Arshad, R., Ahmad, C. S., \& Hamzah, N. A. A. (2010). The impact of ownership structure on stock returns. In 2010 International Conference on Science and Social Research (CSSR 2010) (pp. 217-221). IEEE. https://doi.org/10.1109/CSSR.2010.5773770

Pacecca, T. (1995). An Analysis of Submissions to The Asrb on Release 411 'Foreign Currency TranslationQuestionnaire'. Accounting \& Finance, 35(2), 97-118. https://doi.org/10.1111/j.1467-629X.1995.tb00288.x

Pourciau, S. (1993). Earnings management and nonroutine executive changes. Journal of accounting and economics, 16(1-3), 317-336. https://doi.org/10.1016/0165-4101(93)90015-8

Samiee, S., \& Walters, P. G. (1990). Influence of firm size on export planning and performance. Journal of Business Research, 20(3), 235-248. https://doi.org/10.1016/0148-2963(90)90015-6

Setiono, D. B., Susetyo, B., \& Mubarok, A. (2017). Pengaruh Profitabilitas, Keputusan Investasi, Kebijakan Dividen Dan Kebijakan Hutang Terhadap Nilai Perusahaan (Studi Empiris pada Perusahaan Manufaktur Sektor Industri Barang Konsumsi yang Terdaftar di Bursa Efek Indonesia periode 2011-2015). PERMANA, 8(2).

Slovin, M. B., Johnson, S. A., \& Glascock, J. L. (1992). Firm size and the information content of bank loan announcements. Journal of Banking \& Finance, 16(6), 1057-1071. https://doi.org/10.1016/0378-4266(92)90059-9

Spiess, D. K., \& Affleck-Graves, J. (1995). Underperformance in long-run stock returns following seasoned equity offerings. Journal of Financial Economics, 38(3), 243-267. https://doi.org/10.1016/0304-405X(94)00817-K

Sudarma. (2005). Faktor-faktor Yang Berpengaruh Terhadap Nilai Perusahaan Indonesia. Bussines Conference. Jakarta.

Susilowati, Y., \& Turyanto, T. (2011). Reaksi signal rasio profitabilitas dan rasio solvabilitas terhadap return saham perusahaan. Dinamika Keuangan dan Perbankan, 3(1), 17-37.

Watts, R. L., \& Zimmerman, J. L. (1978). Towards a positive theory of the determination of accounting standards. Accounting review, 112-134.

Watts, R. L., \& Zimmerman, J. L. (1986). Positive accounting theory.

Wolk, H. I., \& Tearney, M. G. (1997). Accounting theory: A conceptual and institutional approach. South Western Educational Publishing.

Zhou, X. (2001). Understanding the determinants of managerial ownership and the link between ownership and performance: comment. Journal of financial economics, 62(3), 559-571. https://doi.org/10.1016/S0304$405 X(01) 00085-\mathrm{X}$

Zimmerman, J. L. (1983). Taxes and firm size. Journal of accounting and economics, 5, 119-149. https://doi.org/10.1016/0165-4101(83)90008-3

Andini, N. L., \& Sukartha, I. M. (2020). The effect of earning management, managerial ownership and firm size in the return of acquisition companies in Indonesia Stock Exchange 2011-2017 period. International Research Journal of Management, IT and Social Sciences, 7(3), 116-125. https://doi.org/10.21744/irjmis.v7n3.928 